\title{
Bursa Ekolojik Koşullarında Yetiştirilen Bazı Tritikale Çeşitlerinin Verim ve Kalite
} Özelliklerinin Belirlenmesi

\section{Canser DOLGUN ${ }^{1}$ iD, Esra AYDOĞAN ÇİFCI $2^{\&}$ ic}

${ }^{1}$ Bursa Uludağ Üniversitesi Fen Bilimleri Enstitüsü Tarla Bitkileri AnaBilim Dalı, Bursa, ${ }^{2}$ Bursa Uludağ Üniversitesi Ziraat Fakültesi Tarla Bitkileri Bölümü, Bursa

${ }^{1}$ https://orcid.org/0000-0002-8036-2962, ${ }^{2}$ https://orcid.org/0000-0002-7473-0140

凹: esra@uludag.edu.tr

\section{ÖZET}

Bu araştırma Türkiye'de tescil edilen 6 tritikale çeşidi (Tatlıcak-97, Presto, Karma-2000, Mikham-2002, Alperbey, Melez-2001) ile 3 yabancı kökenli tritikale çeşidinin (Eronga, Nörtingen, Pol-1) Bursa şartlarında verim ve kalite özelliklerini belirlemek amacıyla 20162017 ve 2017-2018 yıllarında tesadüf blokları deneme desenine göre 3 tekerrürlü olarak Bursa Uludağ Üniversitesi Ziraat Fakültesinde yürütülmüştür. İki ylllık birleştirilmiş varyans analiz sonuçlarına göre başakta tane sayısı özelliği haricinde incelenen diğer özelliklerde genotipler arasındaki farklılıklar ile başakta tane ağırlığı, hektolitre ağırlığı, dekara tane verimi ve protein oranı özelliklerinde genotip $\times$ yıl interaksiyonu önemli bulunmuştur. İki yıllık ortalama değerlere göre genotiplerin bitki boyları 99.6-119.8 cm, başak boyları 9.1-12.6 $\mathrm{cm}$, başakçık sayıları 21.1-29.7 adet, başakta tane sayıları 34.3-54.3 adet, başakta tane ağırlıkları 1.5- $2.8 \mathrm{~g}, 1000$ tane ağırlıkları 37.6$47.0 \mathrm{~g}$, hektolitre ağırlıkları $66.3-72.0 \mathrm{~kg} 100 \mathrm{~L}^{-1}$, tane verimleri $189.2-$ $314.2 \mathrm{~kg} \mathrm{da}^{-1}$ ve protein oranları \% 10.6-12.1 olarak bulunmuştur. Özellikler arası ilişkilerde dekara tane verimi ile başakta başakçık sayısı $\left(r=0,383^{* *}\right)$ ve başakta tane sayısı $\left(r=0,534^{* *}\right)$ arasında pozitif ve önemli ilişki bulunmuştur.
Araştırma Makalesi

\section{Makale Tarihçesi}

Geliş Tarihi : 28.01.2019

Kabul Tarihi : 09.05.2019

\section{Anahtar Kelimeler}

Tritikale

Tane verimi

Kalite

\section{Determination of Yield and Quality Characteristics of Some Triticale Genotypes in Bursa Ecological Conditions}

\section{ABSTRACT}

Objective of this study was to determine the yield and quality characteristics of six triticale varieties, registered in Türkiye (Tatlicak-97, Presto, Karma-2000, Mikham-2002, Alperbey, Melez2001) and three triticale varieties of foreign origin (Eronga, Nörtingen, Pol-1) in a randomized complete block design experiment with three replications conducted in Bursa Uludağ University, Faculty of Agriculture in 2016-2017 and 2017-2018 growing seasons. Results from analyses of variances over two years showed that the differences among the genotypes were significant for all parameters investigated except for number of seeds per spike. Genotype $\times$ year interactions were found to be significant in terms of seed weight per spike, test weight, grain yield and protein content. In the study, means ranged from 99.6-119.8 cm for plant height, 9.1- $12.6 \mathrm{~cm}$ for spike length, 21.1 - 29.7 number of spikelets per spike, $34.3-54.3$ number of seeds per spike, $1.5-2.8 \mathrm{~g}$ seed weight per spike, $37.6-47.0 \mathrm{~g}$ thousand grain weight, $66.3-72.0 \mathrm{~kg} 100 \mathrm{~L}^{-1}$ test weight, $189.2-314.2$ $\mathrm{kg} \mathrm{da}{ }^{-1}$ for grain yield, \% $10.6-12.1$ for protein content. Statistically and positively significant relation were determined between grain yield and number of spikelets per spike $\quad\left(r=0.383^{* *}\right)$, number of seeds per spike $\left(r=0.534^{* *}\right)$.

\section{Research Article}

\author{
Article History \\ Geliş Tarihi : :28.01.2019
}

Kabul Tarihi : 09.05 .2019

Keywords

Triticale

Grain yield

Quality 


\section{GİRIŞ}

Tahillar hem insan hem de hayvan beslenmesinde önemli bir yer almakta ve üretimleri dünya tarım alanlarının büyük çoğunluğunda yapılmaktadır. Giderek artan dünya nüfusunun yeterli ve dengeli beslenebilmesi amaciyla ekim alanlarının ve birim alana tane verimlerinin artırılmasına yönelik çalışmalar sürerken, yeni ürün gruplarının belirlenmesi çalışmaları da hız kazanmıştır. $\mathrm{Bu}$ konudaki ilk başarılı çalışma tritikalenin eldesiyle gerçekleşmiştir. Çavdarın adaptasyon ve dayanıklılık yeteneği ile buğdayın verim ve kalitesini birleştirmeyi amaçlayan melezleme çalışmaları 1875 yıllarında başlamış ve ilk ticari çeşitler 1968 yılında üreticiye verilmiştir (Kün, 1996).

Serin iklim tahılları içerisinde marjinal alanların değerlendirilmesinde tritikalenin öncelikli bitki olduğu ve ekim alanı ve üretiminde önemli artışların sağlanabilmesi için yeni çeşitlerin geliştirilmesi gerektiği belirtilmektedir (Kün, 1996). Dünyada yazlık ve kışlık olarak yetiştirilen tritikale çeşitleri mevcut olup, günümüzde tane tipi olarak hekzaploid tritikalenin, çayır tipi olarak oktoploid tritikalenin üzerinde durulmaktadır. Tritikale tek başına ekilebildiği gibi tek yıllık baklagil yem bitkileri ile karışık olarak da ekilebilmektedir. Taneleri hayvan yemi olarak değerlendirildiği gibi, buğday ve çavdar ununa karıştırılarak, ekmek, pasta ve bisküvi yapımında da kullanılmaktadır (Ünver, 1999).

Türkiye'de Bakırçay tritikale çeşidi üretim izinli olarak ilk kez yetiştirilmeye başlamış, daha sonra Tatlicak-97, Tacettinbey, Presto ve Karma-2000 çeşitleri tescil edilmiştir. Tritikale üzerinde çalışan araştırmacılar verim, çeşit adaptasyonu ve kalite özellikleriyle ilgili çeşitli araştırmalar yaparak bu konuda oldukça yol kaydetmişlerdir.

Bu çalışmada, Türkiye'de tescil edilen 6 tritikale çeşidi ile yurt dışı orjinli 3 tritikale çeşidinin Bursa ekolojik koşullarında verim ve kalite özelliklerinin belirlenmesi amaçlanmıştır.

\section{MATERYAL ve METOT}

$\mathrm{Bu}$ araştırma 2016-2017 ve 2017-2018 yıllarında Bursa Uludağ Üniversitesi Ziraat Fakültesi Tarımsal Uygulama ve Araştırma Merkezinde yürütülmüştür. Denemede Türkiye'de geliştirilen 6 tritikale çeşidi (Tatlıcak-97, Presto, Karma-2000, Mikham-2002, Alperbey, Melez-2001) ile yurt dışı orjinli 3 tritikale çeşidi (Eronga, Nörtingen, Pol-1) bitki materyali olarak kullanılmıştır (Çizelge 1).

Çizelge 1. Denemede Kullanılan Tritikale Çeşitleri

\begin{tabular}{|l|l|}
\hline Tritikale Çeşitleri & Tescil Edildiği Ülke \\
\hline Tatlıcak-97 & Türkiye / Bahri Dağdaş Uluslararası Tarımsal Araştırma Enstitüsü Müdürlüğü \\
\hline Presto & Türkiye / Geçit Kuşağı Tarımsal Araştırma Enstitüsü Müdürlüğü \\
\hline Karma-2000 & Türkiye / Geçit Kuşağı Tarımsal Araştırma Enstitüsü Müdürlüğü \\
\hline Mikham-2002 & Türkiye / Bahri Dağdaş Uluslararası Tarımsal Araştırma Enstitüsü Müdürlüğü \\
\hline Alperbey & Türkiye / Bahri Dağdaş Uluslararası Tarımsal Araştırma Enstitüsü Müdürlügü \\
\hline Melez-2001 & Türkiye / Bahri Dağdaş Uluslararası Tarımsal Araştırma Enstitüsü Müdürlüğü \\
\hline Eronga & Meksika /CIMMYT \\
\hline Nörtingen & Almanya \\
\hline *Pol-1 & Polonya \\
\hline
\end{tabular}

*Çeşidin asıl ismi bilinmediği için Pol-1 olarak kodlanmıştır.

Araştırma alanın toprakları ağır ve orta bünyeli, $\mathrm{pH}$ 'sı 7.4 ve tuzsuzdur. Organik maddece fakir olan toprak orta derecede kireçli, fosforca zengin, potasyumca çok zengindir (Deveciler, 2005). Çizelge 2'deki denemenin yürütüldüğü yıllara ait iklim verilerinden görüleceği gibi her iki yılda da aylık toplam yağış miktarı uzun yıllar ortalamasından daha düşük olmuştur. Uzun yıllar ortalamasında aylık ortalama sicaklık değerleri $13.7^{\circ} \mathrm{C}$ iken $2016-2017$ yetiştirme döneminde $12.2^{\circ} \mathrm{C}$ ve 2017-2018 yetiştirme döneminde $14.3^{\circ} \mathrm{C}$ olarak belirlenmiştir (Anonim, 2018).

Araştırma tesadüf blokları deneme desenine göre 3 tekerrürlü olarak kurulmuştur. Parsel boyutları $1.2 \times$ $5=6 \mathrm{~m}^{2}$ olacak şekilde parselizasyon yapılmıştır. Parsellere $\mathrm{m}^{2}$ 'ye 550 tohum gelecek şekilde Kasım ayında ekim yapılmıştır. Ekimle birlikte $5 \mathrm{~kg} \mathrm{~N}$ da-1 olacak şekilde 20-20-0 gübresi,sapa kalkma zamanında ise yine $10 \mathrm{~kg} \mathrm{~N} \mathrm{da-1}$ üre gübresi verilmiştir. Dar ve geniş yapraklı yabancı otların kontrolü için sırasıyla Illoxan ( $200 \mathrm{~mL}$ da) ve Mustang $(50 \mathrm{~mL} \mathrm{da})$ herbisitleri uygulanmıştır. Hasat her iki yılda da Temmuz ayında yapılmıştır. Çalışmada bitki boyu, başak boyu, başakçık sayısı, başakta tane sayısı, başakta tane ağırlığı, bin tane ağırlığ ağırlığı, protein oranı ve dekara tane verimi özellikleri incelenmiştir. İncelenen özelliklere ait veriler JUMP istatistik paket programı kullanılarak varyans analizi yapılmış ve ortalamalar arasındaki farklılıklar LSD (\%5) testiyle hesaplanmıştır. 
Çizelge 2. Bursa ilinin deneme yılları ile uzun yıllar ortalama yağış ve sıcaklık verileri

\begin{tabular}{lllllll}
\hline \multirow{2}{*}{ Aylar } & \multicolumn{5}{l}{ Toplam Yağ ${ }_{1 S ̧}(\mathrm{~mm})$} & \multicolumn{5}{l}{ Ortalama Sicaklık $\left({ }^{\circ} \mathrm{C}\right)$} \\
\cline { 2 - 6 } & $2016-2017$ & $2017-2018$ & $\begin{array}{l}\text { Uzun y1llar } \\
(1970-2011)\end{array}$ & $2016-2017$ & $2017-2018$ & $\begin{array}{l}\text { Uzun yıllar } \\
(1970-2011)\end{array}$ \\
\hline Kasım & 66.0 & 34.1 & 81.3 & 10.9 & 10.7 & 10.4 \\
Aralık & 114.3 & 102.6 & 101.4 & 2.8 & 9.7 & 13.0 \\
Ocak & 96.4 & 50.6 & 79.4 & 3.2 & 6.3 & 7.9 \\
Subat & 19.9 & 108.9 & 71.0 & 7.4 & 8.8 & 7.6 \\
Mart & 17.7 & 76.0 & 66.8 & 9.7 & 12.2 & 6.7 \\
Nisan & 38.1 & 15.0 & 65.9 & 12.2 & 14.8 & 13.0 \\
Mayıs & 33.3 & 72.7 & 44.2 & 17.2 & 18.8 & 17.7 \\
Haziran & 56.4 & 29.2 & 34.1 & 22.1 & 22.6 & 22.4 \\
Temmuz & 18.9 & 14.5 & 17.4 & 24.6 & 25.2 & 24.6 \\
Top./Ort. & 461.0 & 503.6 & 561.5 & 12.2 & 14.3 & 13.7 \\
\hline
\end{tabular}

\section{BULGULAR ve TARTIŞMA}

Bursa ekolojik koşullarında 2 yıl boyunca yetiştirilen 9 tritikale genotipinin verim ve kalite özelliklerinin belirlenmesi amacıyla yürütülen bu çalışmada ele alınan özelliklere ait genotiplerin birleştirilmiş varyans analiz sonuçları Çizelge 3'de verilmiştir. Yapılan varyans analiz sonuçlarına göre başakta tane sayısı, bin tane ağırlığı özelliği haricinde incelenen diğer özelliklerde genotipler arasındaki farklılıklar ile başakta tane ağırlığı, hektolitre ağırlığ 1 , tane verimi ve protein oranı özelliklerinde genotip $\times$ yıl interaksiyonu önemli bulunmuştur. Bitki boyu, başakçık sayısı, başakta tane sayısı, başakta tane ağırlığı, hektolitre ağırlığ 1 ve protein oranı özelliklerinde yıllar arasında istatistiki olarak \%1 olasılık düzeyinde önemlilik saptanmiştır.

\section{Bitki Boyu (cm)}

İlk yıl en uzun bitki boyu $119.6 \mathrm{~cm}$ ile Tatlıcak-97 ve $117.3 \mathrm{~cm}$ ile Presto çeşitlerinde bulunurken, en kısa bitki boyu $92.6 \mathrm{~cm}$ ile Pol-1 çeşidinde görülmüştür. İkinci yıl genotipler arası farklar önemsiz bulunurken ortalama bitki boyu 108.4-120.0 cm arasında değişim göstermiştir. İki yıllık ortalamada Karma-2000 (119.9 $\mathrm{cm})$ ve Tatlıcak-987 (119.8 cm) en uzun boylu çeşitler olmuştur. En kısa bitkiler ise 100.5 cm ile Pol-1 ve 99.6 $\mathrm{cm}$ ile Alper Bey çeşitlerinde bulunmuştur (Çizelge 4). Çalışmada bulunan sonuçlar Furan ve ark. (2005) ve
Mut ve ark. (2006)'nın yaptıkları araştırma sonuçları ile benzerlik göstermiştir.

\section{Başak Boyu (cm)}

İlk yıl en uzun başaklar $(12.0 \mathrm{~cm})$ Tatlıcak-97 çeşidinde ölçülürken, en kısa başaklar $7.6 \mathrm{~cm}$ ile Alperbey çeşidinde bulunmuştur. İkinci yıl ise en uzun başak $(13.8 \mathrm{~cm}$ ) Melez-2001, en kısa başak ise $(8.8 \mathrm{~cm})$ Alperbey çeşidinde belirlenmiştir. İki yıllık ortalamada Melez-2001 en uzun başak $(12.6 \mathrm{~cm})$ oluştururken Alperbey $(8.2 \mathrm{~cm})$ en kısa başaklara sahip olmuştur (Çizelge 4). Tritikale ile yürütülen diğer çalışmalarda; başak boyları Paksoy (2005) tarafından 8.6-13.8 cm arasında, Atak ve Çiftçi (2006) tarafindan 8.5-10.8 $\mathrm{cm}$ arasında ve Akgün ve ark. (2007) tarafindan ise $6.5-8.5 \mathrm{~cm}$ arasında ölçülmüştür. Çalışmadaki çeşitlerin başak uzunluğuna ait ortalama değerler, Gülmezoğlu ve ark. (2007) ile Tayyar ve Kahrıman (2016)'nın yaptıkları çalışmalarla benzerlik göstermiştir.

\section{Başakta Başakçıı Sayısı (adet)}

Başakta başakçık sayısı özelliğinde ise, tritikale çeşitlerinde ilk yıl en fazla başakta başakçık sayısı 29.7 adet ile Pol-1 çeşidinde bulunurken, en az başakta başakçık sayısı 18.7 adet ile Alperbey çeşidinde bulunmuştur.

Çizelge 3. İncelenen özelliklere ait varyans analiz sonuçları

\begin{tabular}{lllllllllll}
\hline V.K. & SD & BB & BAB & BS & BTS & BTA & $\begin{array}{l}\text { 1000 } \\
\text { TA }\end{array}$ & HA & PO & TV \\
\hline Genotip(G) & 8 & $319.4^{* *}$ & $10.4^{* *}$ & $53.5^{* *}$ & 181.1 & $1.07^{* *}$ & 2358.5 & $21.7^{* *}$ & $1.1^{* *}$ & $12677.1^{* *}$ \\
Tekerrür & 2 & 168.2 & 0.15 & 1.1 & 60.0 & 0.001 & 2241.7 & 1.08 & 0.001 & 2233.9 \\
Yll (Y) & 1 & $1177.8^{* *}$ & 3.7 & $138.8^{* *}$ & $4743.3^{* *}$ & $3.8^{* *}$ & 14.1 & $503.5^{* *}$ & $12.7^{* * *}$ & 8.40 \\
G $\times$ Y & 8 & 76.9 & 2.1 & 5.6 & 141.3 & $0.96^{* *}$ & 2341.4 & $15.7^{* *}$ & $1.3^{* *}$ & $8214.4^{* *}$ \\
Hata & 34 & 52.2 & 1.2 & 6.1 & 96.6 & 0.16 & 2240.9 & 0.42 & 0.16 & 1440.36
\end{tabular}

Genel 53

BB: Bitki boyu, BAB: Başak boyu, BS: Başakçık sayısı, BTS: Başakta tana sayısı, BTA: Başakta tane ağırlığı, 1000 TA: 1000 tane ağırlığı, HA: Hektolitre ağırlığı, PO: Protein oranı, TV: tane verimi

** $: \mathrm{P} \leq 0.01$ düzeyinde önemli. 
Çizelge 4. Tritikale genotiplerinin incelenen özelliklere ait yıllar ve iki yıllık ortalama değerleri

\begin{tabular}{|c|c|c|c|c|c|c|c|c|c|}
\hline Genotipler & $\begin{array}{l}\mathrm{BB} \\
(\mathrm{cm})\end{array}$ & $\begin{array}{l}\text { BAB } \\
(\mathrm{cm})\end{array}$ & $\begin{array}{l}\text { BS } \\
\text { (adet) }\end{array}$ & $\begin{array}{l}\text { BTS } \\
\text { (adet) }\end{array}$ & $\begin{array}{l}\text { BTA } \\
(\mathrm{gr})\end{array}$ & $\begin{array}{l}1000 \mathrm{TA} \\
(\mathrm{gr})\end{array}$ & $\begin{array}{l}\mathrm{HA} \\
\left(\mathrm{kg} 100 \mathrm{~L}^{-1}\right)\end{array}$ & $\begin{array}{l}\mathrm{PO} \\
(\%)\end{array}$ & $\begin{array}{l}\text { DTV } \\
(\mathrm{kg} \mathrm{da-1)}\end{array}$ \\
\hline \multicolumn{10}{|c|}{ 1.Yil (2016-2017) } \\
\hline Tatlicak-97 & $119.6 \mathrm{a}$ & $12.0 \mathrm{a}$ & $27.7 \mathrm{ab}$ & $37.8 \mathrm{ab}$ & $1.8 \mathrm{ab}$ & 47.7 & 67.2 & $12.7 \mathrm{a}$ & $214.8 \mathrm{~cd}$ \\
\hline Presto & $117.3 \mathrm{a}$ & $9.3 \mathrm{c} \mathrm{d}$ & $25.1 \mathrm{bc}$ & $36,1 \mathrm{a}^{-\mathrm{c}}$ & $1.8 \mathrm{ab}$ & 52.9 & 69.6 & $12.0 \mathrm{~b}$ & $229.1 \mathrm{c}$ \\
\hline Eronga & $107.3 \mathrm{c}$ & $8.7 \mathrm{de}$ & $22.1 \mathrm{~cd}$ & $24.7 \mathrm{c}$ & $1.3 \mathrm{c}$ & 52.9 & 72.0 & $11.9 \mathrm{~b}$ & $194.2 \mathrm{~d}$ \\
\hline Nörtingen & $105.4 \mathrm{c}$ & $9.1 \mathrm{~cd}$ & $22.3 \mathrm{~cd}$ & $32.3 \mathrm{a}^{-c}$ & $2.1 \mathrm{a}$ & 49.0 & 74.6 & $11.6 \mathrm{c}$ & $313.3 \mathrm{a}$ \\
\hline Karma-2000 & $115.1 \mathrm{ab}$ & $9.9 \mathrm{~cd}$ & $25.6 \mathrm{a}^{-\mathrm{c}}$ & $42.6 \mathrm{a}$ & $2.1 \mathrm{a}$ & 48.4 & 77.0 & $11.0 \mathrm{e}$ & $240.8 \mathrm{c}$ \\
\hline Mikham-2002 & 109.8 bc & $9.8 \mathrm{~cd}$ & $25.7 \mathrm{a}^{-\mathrm{c}}$ & $40.5 \mathrm{a}$ & $1.9 \mathrm{ab}$ & 47.4 & 75.2 & $11.6 \mathrm{c}$ & 231.0 c \\
\hline Alperbey & $90.2 \mathrm{~d}$ & $7.6 \mathrm{e}$ & $18.7 \mathrm{~d}$ & $27.8 \mathrm{bc}$ & $1.3 \mathrm{c}$ & 48.4 & 72.6 & $11.3 \mathrm{~d}$ & $196.3 \mathrm{~d}$ \\
\hline Melez-2001 & $105.6 \mathrm{c}$ & $11.4 \mathrm{ab}$ & $27.9 \mathrm{ab}$ & $28.5 \mathrm{bc}$ & $1.4 \mathrm{c}$ & 48.8 & 71.8 & $10.9 \mathrm{e}$ & $199.1 \mathrm{~d}$ \\
\hline Pol-1 & $92.6 \mathrm{~d}$ & $10.2 \mathrm{bc}$ & $29.7 \mathrm{a}$ & $39.3 \mathrm{ab}$ & $1.5 \mathrm{bc}$ & 40.7 & 73.4 & $12.1 \mathrm{~b}$ & $279.9 \mathrm{~b}$ \\
\hline Ortalama & 106.9 & 9.7 & 24.9 & 34.4 & 1.7 & 48.5 & 72.6 & 11.7 & 233.2 \\
\hline LSD 0.05 & 6.9 & 1.3 & 4.3 & 11.7 & 0.35 & & & 0.23 & 26.8 \\
\hline \multicolumn{10}{|c|}{ 2.Yil (2017-2018) } \\
\hline Tatlicak-97 & 120.0 & $10.8 \mathrm{~b}$ & $29.6 \mathrm{ab}$ & $47.0 \mathrm{c}$ & $2.0 \mathrm{~b}$ & 34.2 & $65.4 \mathrm{de}$ & $11.4 \mathrm{ab}$ & $167.9 \mathrm{~b}$ \\
\hline Presto & 113.2 & $9.0 \mathrm{bc}$ & $27.0 \mathrm{~b}-\mathrm{d}$ & $44.5 \mathrm{c}$ & $1.5 \mathrm{~b}$ & 34.8 & $65.0 \mathrm{e}$ & $10.9 \mathrm{ab}$ & $163.8 \mathrm{~b}$ \\
\hline Eronga & 120.0 & $9.6 \mathrm{bc}$ & $25.8 \mathrm{~cd}$ & $44.0 \mathrm{c}$ & $1.7 \mathrm{~b}$ & 41.1 & $68.0 \mathrm{bc}$ & $10.5 \mathrm{~b}$ & $353.6 \mathrm{a}$ \\
\hline Nörtingen & 116.1 & $9.7 \mathrm{bc}$ & $25.6 \mathrm{~cd}$ & $62.0 \mathrm{ab}$ & $3.6 \mathrm{a}$ & 39.7 & $66.8 \mathrm{~cd}$ & $10.9 \mathrm{ab}$ & $315.0 \mathrm{a}$ \\
\hline Karma-2000 & 124.7 & $10.7 \mathrm{~b}$ & $31.0 \mathrm{a}$ & $50.0 \mathrm{bc}$ & $1.9 \mathrm{~b}$ & 38.4 & $64.4 \mathrm{e}$ & $11.6 \mathrm{a}$ & $314.0 \mathrm{a}$ \\
\hline Mikham-2002 & 118.4 & $10.7 \mathrm{~b}$ & $30.8 \mathrm{ab}$ & $45.5 \mathrm{c}$ & $1.6 \mathrm{~b}$ & 33.8 & 68.9ab & $10.8 \mathrm{ab}$ & $222.5 \mathrm{~b}$ \\
\hline Alperbey & 109.1 & $8.8 \mathrm{c}$ & $23.5 \mathrm{~d}$ & $56.6 \mathrm{a}^{-c} \mathrm{c}$ & $2.9 \mathrm{a}$ & 46.4 & $69.6 \mathrm{a}$ & $10.6 \mathrm{~b}$ & $188.1 \mathrm{~b}$ \\
\hline Melez-2001 & 117.1 & $13.8 \mathrm{a}$ & $31.4 \mathrm{a}$ & $50.5 \mathrm{bc}$ & $1.8 \mathrm{~b}$ & 34.7 & $64.5 \mathrm{e}$ & $10.5 \mathrm{~b}$ & $179.4 \mathrm{~b}$ \\
\hline Pol-1 & 108.4 & $9.1 \mathrm{bc}$ & $29.0 \mathrm{a}^{-\mathrm{c}}$ & $69.3 \mathrm{a}$ & $3.1 \mathrm{a}$ & 34.4 & $65.7 \mathrm{de}$ & $9.1 \mathrm{c}$ & $201.9 \mathrm{~b}$ \\
\hline Ortalama & 116.3 & 10.2 & 28.2 & 52.2 & 2.28 & 37.5 & 66.5 & 10.7 & 234.0 \\
\hline LSD 0.05 & & 1.8 & 3.7 & 14.3 & 0.7 & & 1.5 & 0.9 & 90.0 \\
\hline \multicolumn{10}{|c|}{ İki Yıllık Ortalama Değerler } \\
\hline Tatlicak-97 & $119.8 \mathrm{a}$ & $11.4 \mathrm{ab}$ & $28.7 \mathrm{ab}$ & 42.4 & $1.9 \mathrm{~b}-\mathrm{e}$ & 40.9 & $66.3 \mathrm{~g}$ & $12.1 \mathrm{a}$ & $191.4 \mathrm{~d}$ \\
\hline Presto & $115.2 \mathrm{ab}$ & $9.1 \mathrm{~cd}$ & $26.0 \mathrm{bc}$ & 40.3 & $1.7 \mathrm{c}^{-} \mathrm{e}$ & 43.8 & $67.3 \mathrm{f}$ & $11.4 \mathrm{~b}$ & $196.5 \mathrm{~cd}$ \\
\hline Eronga & $113.7 \mathrm{ab}$ & $9.2 \mathrm{~cd}$ & $23.9 \mathrm{~cd}$ & 34.3 & $1.5 \mathrm{e}$ & 47.0 & $70.0 \mathrm{~cd}$ & $11.2 \mathrm{bc}$ & $273.9 \mathrm{ab}$ \\
\hline Nörtingen & $110.8 \mathrm{~b}$ & $9.4 \mathrm{~cd}$ & $23.9 \mathrm{~cd}$ & 47.1 & $2.8 \mathrm{a}$ & 44.3 & $70.7 \mathrm{bc}$ & $11.2 \mathrm{bc}$ & $314.2 \mathrm{a}$ \\
\hline Karma-2000 & $119.9 \mathrm{a}$ & $10.3 \mathrm{bc}$ & $28.3 \mathrm{ab}$ & 41.8 & $2.0 \mathrm{~b}-\mathrm{d}$ & 43.4 & $70.7 \mathrm{bc}$ & $11.3 \mathrm{bc}$ & $277.4 \mathrm{ab}$ \\
\hline Mikham-2002 & $114.1 \mathrm{ab}$ & $10.0 \mathrm{c}$ & $28.2 \mathrm{ab}$ & 43.0 & $1.8 \mathrm{c}^{-} \mathrm{e}$ & 40.6 & $72.0 \mathrm{a}$ & $11.2 \mathrm{bc}$ & $266.8 \mathrm{~cd}$ \\
\hline Alperbey & $99.6 \mathrm{c}$ & $8.2 \mathrm{~d}$ & $21.1 \mathrm{~d}$ & 42.2 & $2.1 \mathrm{bc}$ & 44.4 & $71.1 \mathrm{~b}$ & $10.9 \mathrm{~cd}$ & $192.2 \mathrm{~d}$ \\
\hline Melez-2001 & $111.3 \mathrm{~b}$ & $12.6 \mathrm{a}$ & $29.7 \mathrm{a}$ & 39.5 & $1.6 \mathrm{de}$ & 41.8 & $68.1 \mathrm{e}$ & $10.1 \mathrm{~d}$ & $189.2 \mathrm{~d}$ \\
\hline Pol-1 & $100.5 \mathrm{c}$ & $9.6 \mathrm{c}$ & $29.4 \mathrm{a}$ & 54.3 & $2.3 \mathrm{~b}$ & 37.6 & $69.5 \mathrm{~d}$ & $10.6 \mathrm{~d}$ & $240.9 \mathrm{bc}$ \\
\hline Ortalama & 111.7 & 9.9 & 23.9 & 42.8 & 1.9 & 42.6 & 69.5 & 11.1 & 238.1 \\
\hline LSD 0.05 & 8.4 & 1.2 & 2.8 & & 0.4 & & 0.7 & 0.4 & 44.38 \\
\hline
\end{tabular}

BB: Bitki boyu, BAB: Başak boyu, BS: Başakçık sayısı, BTS: Başakta tana sayısı, BTA: Başakta tane ağırlığı, 1000 TA: 1000 tane ağırlığı, HA: Hektolitre ağırlığı, PO: Protein oranı, DTV: Dekara tane verimi

İkinci yıl ise en fazla başakta başakçık sayısı 31.0 adet ile Karma-2000 ve 31.4 adet ile Melez-2001 çeşitlerinde bulunurken, en az başakta başakçık sayısı 23.5 adet ile Alperbey çeşidinde bulunmuştur. İki yıllık ortalama değerlere bakıldığında en fazla başakta başakçık sayısı 29.7 adet ile Melez-2001 ve 29.4 adet ile Pol-1 çeşitlerinde bulunuş olup en az başakta başakçık sayısı ise 21.1 adet ile Alperbey çeşidinde bulunulmuştur (Çizelge 4). Çalışmadaki çeşitlerin başakta başakçık sayısına ait ortalama değerleri ile Atak ve Çiftçi (2006) ve Demirel (2004)'in buldukları ortalama değerler benzerlik göstermiştir.

\section{Başakta Tane Sayısı (adet)}

Başakta tane sayısı özelliği açısından, tritikale çeşitlerinde ilk yıl en fazla başakta tane sayısı 42.6 adet ile Karma-2000 ve 40.5 adet ile Mikham-20022002 çeşidinde bulunurken ikinci yılda ise en fazla başakta tane sayısı Pol-1 çeşidinde gözlenmiştir. Çeşitler arasında başakta tane sayısı özelliğine ait iki yıllık ortalama değerleri önemsiz bulunmuş olup 34.3 ile 54.3 adet arasında değişmektedir (Çizelge 4). Tritikalede başakta tane sayısı ile ilgili yapılan çalışmalarda, Genç ve ark. (1987) başakta tane sayısını 37.9-50.7 adet, Ankara şartlarında Atak ve Çiftçi (2006) 39.3-53.9 adet, Diyarbakır şartlarında Alp (2009), 36.1-40.3 adet, Tayyar ve Kahrıman (2016) 
ise Biga koşullarında 20.9-30.7 adet olarak değiştiğini belirtmişlerdir. Araştırıcıların elde ettikleri sonuçlar ile bu çalışmada elde edilen başakta tane sayısı değerleri benzerlik göstermiştir.

\section{Başakta Tane Ağırlığı (g)}

Tritikale çeşitlerine ait başakta tane ağırlığı ilk yıl 1.3 ile 2.1 gram arasında, ikinci yll ise 1.5 ile 3.6 gram arasında değiştiği görülmektedir. İki yıllık ortalama değerler bakımından başakta tane ağırlığı en fazla 2.8 gram ile Nörtingen çeşidinde, en az ise 1.5 gram ile Eronga çeşidinde bulunmuştur (Çizelge 4). Türkiye'de farklı ekolojik koşullar yapılan çalışmalarda başakta tane ağırlığının farklılık gösterdiği görülmüştür (Gülmezoğlu ve ark.,2007; Tayyar ve Kahrıman 2016).

\section{Tane Ağırlığ}

Tritikale çeşitlerine ait bin tane ağırlığı ilk yıl 40.7 ile 52.9 gram arasında, ikinci yl 46.4 ile 33.8 gram arasında ve iki yıllık ortalama değerlere bakıldığında ise 37.6 ile 47.0 gram arasında değiştiği görülmektedir (Çizelge 4). 1000 tane ağırlığı değerini Aydın ve ark. (2007), 32.4-43.2 g, Kaya ve Şanlı (2009), 41.55 g, Ülker (2017) 30.42-38.67 g ve Lermi ve Palta (2018) ise 24.64-35.97 gr arasında belirleyerek çalışmada belirlenen sonuçlara paralel sonuçlar elde etmişledir.

\section{Hektolitre Ağırlığı (kg 100L-1)}

Hektolitre ağırlığı özelliği bakımından tritikale çeşitlerine ait hektolitre ağırlığ ilk yıl istatistiki olarak önemsiz bulunurken, ikinci yll ise 69.6 ile 72.0 $\mathrm{kg}$ arasında değiştiği görülmektedir. İki yıllık ortalama değerler bakımından en fazla hektolitre ağırlığı $72.0 \mathrm{~kg}$ ile Mikham-2002 çeşidinde, en az ise $66.3 \mathrm{~kg}$ ile Tatlıcak -97 çeşidinde bulunmuştur (Çizelge 4). Bu çalışmada elde edilen hektolitre ağırlığı değerleri ile Yağbasanlar (1987)'ın Çukurova koşullarında 7 tritikale çeşidini kullanarak yaptıkları çalışmada $66.2^{-7} 71.2 \mathrm{~kg}$ arasında değişen hektolitre ağırlığı değerleri ile benzerlik göstermektedir.

\section{Protein Oranı (\%)}

Çeşitlerin protein oranı incelendiğinde, birinci yıl çeşitlerin protein oranları \%12.7-10.9 arasında değişirken, ikinci yıl \% 11.6-9.1 arasında bulunmuştur. İki ylllk ortalama değerlere bakıldığında en fazla protein oranı \% 12.1 ile Tatlıcak97 çeşidinde, en düşük protein oranı ise \%10.6 ile $\mathrm{Pol}^{-}$ 1 ve \%10.1 ile Melez 2001 çeşitlerinde bulunmuştur (Çizelge 4). Araştırmada tritikale çeşitlerinden elde edilen protein oranları ile Gülmezoğlu ve ark. (2007)'nın Orta Anadolu Bölgesi koşullarında yaptıkları araştırmada protein oranı \% 10.9-11.5 değerleri ve Tayyar ve Kahrıman (2016)'nın Biga koşullarında Tritikalede yaptıkları çalışmada elde ettikleri protein içerikleri olan \%12.0-9.8 oranları ile benzerlik göstermektedir. Ayrıca tritikale bitkisi üzerinde yapılan diğer araştırmalarda protein içerikleri, Erekul ve Köhn (2006) tarafından \% 10.917.0, Tohver ve ark. (2005) tarafindan \% 9.7-14.5, Akgün ve ark. (2007) tarafindan \% 10.3-12.7, Alp (2009) tarafından \% 10.63-11.43 olarak belirlenmiştir.

\section{Dekara Tane Verimi (kg da-1)}

Dekara tane verimi özelliği açısından birinci yıl çeşitlerin verimleri $194.2-313.3 \mathrm{~kg} \mathrm{da}^{-1}$ arasında değişirken, ikinci yıl $163.8^{-353.6} \mathrm{~kg} \mathrm{da}^{-1}$ arasında bulunmuştur. İki yıllık ortalama değerlere bakıldığında en fazla verim $314.2 \mathrm{~kg} \mathrm{da}^{-1}$ ile Nörtingen, $277.4 \mathrm{~kg} \mathrm{da}^{-1}$ ile Karma-2000 ve $273.9 \mathrm{~kg} \mathrm{da}^{-1}$ ile Eronga çeşitlerinde, en düşük verim ise $182.2 \mathrm{~kg} \mathrm{da}^{-1}$ ile Melez-2001 çeşidinde bulunmuştur (Çizelge 4). Farklı ekolojik koşullarda yapılan çalışmalarda verimin farklılık gösterdiği görülmüştür. Araştırmada kullanılan tritikale çeşitlerinin bir kısmını kullanarak yürüttükleri çalışmalarında, Alp (2009) Diyarbakır koşullarında farklı tritikale çeşitlerini tohum verimini $378.18-478.30 \mathrm{~kg} / \mathrm{da}$ arasında arasında elde ettiğini bildirirken Mut ve ark. (2006), Amasya ve Samsun koşularında yürüttükleri araştırmada Presto ve Tatlıcak 97 çeşitlerinin tane verimi sırasıyla 470.7 ve $449.1 \mathrm{~kg} / \mathrm{da}$ olarak tespit etmiştir. Kutlu ve Kınacı (2011) Eskişehir koşullarında tritikale tane veriminin kuru koşullarda 383.79-668.52 kg/da sulu koşullarda ise $699.53-1081.94 \mathrm{~kg} / \mathrm{da}$ arasında değiştiğini, Geren ve ark. (2012) ise Menemen koşularında tritikale çeşitlerinin tane verimini $368-539 \mathrm{~kg} / \mathrm{da}$ arasında elde ettiğini bildirmiştir. Mut ve Erbaş Köse (2018) Yozgat koşullarında tritikale hatların tane verimi ve bazı özelliklerini araştırmışlar ve çalışmanın sonucunda tohum verimini Melez 2001, Mikham 2002, Karma 2000 ve Tatlıcak 97 çeşitlerinde sırasıyla 254.4, 276.1, $335.2,340.2 \mathrm{~kg} /$ da olarak elde etmiştir. Lermi ve Palat (2018) ise Batı Karadeniz ekolojisinde Bartın Koşullarında Tatlıcak 97, Melez 2001, Mikham 2002, Karma 2000 ve Presto çeşitlerini kullanarak yürüttükleri çalışmalarında tane verimlerini 325.8$805.8 \mathrm{~kg} / \mathrm{da}$ olarak belirlemişlerdir.

\section{Özellikler Arası İlişkiler}

Çizelge 5'te araştırmada incelenen özelliklere ait korelasyon katsayıları verilmiştir. Tane verimi ile başakçık sayısı $\left(r=0.383^{* *}\right)$, başakta tane sayısı $(r=$ $0.534^{* *}$ ) arasında pozitif önemli ilişki bulunmuştur. Bitki boyu ile başak boyu $\left(r=0.467^{* *}\right)$, başakçık sayısı $\left(\mathrm{r}=0.497^{* *}\right)$ arasında pozitif ve önemli ilişkiler belirlenirken bitki boyu ve hektolitre ağırlığı $(r=$ $0.473^{* *}$ ) arasında negatif önemli ilişki bulunmuştur. Başak boyu ile başakta başakçık sayısı $\left(r=0.733^{* *}\right)$, başakta başakçık sayısı ile başakta tane sayısı ( $\mathrm{r}=$ $\left.0.409^{* *}\right)$, hektolitre ağırlığ $\left(r=-0.477^{* *}\right)$ arasinda, başakta tane sayısı ile tane ağırlığ $\left(\mathrm{r}=0.753^{* *}\right)$ arasında pozitif önemli ve hektolitre ağırlığ $\quad(\mathrm{r}=$ - 
$0.550 * *)$ arasında negatif önemli ilişkiler belirlenmiştir. Protein oranı ile başakta tane sayısı $(r$ $\left.=-0.488^{* *}\right)$ ve tane ağırlığı $\left(r=-0.412^{* *}\right)$ arasinda negatif önemli önemli ilişkiler bulunmuştur. Benzer sonuçlar Ülger ve ark. (1989), Yücel ve ark. (2009), Polat ve ark. (2015) ve Tonk ve ark. (2017)'nın çalışmalarında da saptanmıştır.

Çizelge 5: İncelenen özellikler arası korelasyon katsayıları

\begin{tabular}{|c|c|c|c|c|c|c|c|c|c|}
\hline & & $\begin{array}{l}\text { Bitki } \\
\text { Boyu }\end{array}$ & $\begin{array}{l}\text { Başak } \\
\text { Boyu }\end{array}$ & $\begin{array}{l}\text { Başakçık } \\
\text { Sayısı }\end{array}$ & $\begin{array}{l}\text { Başakta } \\
\text { Tane } \\
\text { Sayısı }\end{array}$ & $\begin{array}{l}\text { Başakta } \\
\text { Tane } \\
\text { Ağırlığ } \\
\end{array}$ & $\begin{array}{l}1000 \text { Tane } \\
\text { Ağırlığı }\end{array}$ & $\begin{array}{l}\text { Hektolitre } \\
\text { Ağırlığı }\end{array}$ & $\begin{array}{l}\text { Dekara } \\
\text { Tane } \\
\text { Verim }\end{array}$ \\
\hline \multicolumn{2}{|c|}{ Başak Boyu } & $0.467 * *$ & & & & & & & \\
\hline \multicolumn{2}{|c|}{ Başakçık Sayısı } & $0.497 * *$ & $0.733^{* *}$ & & & & & & \\
\hline \multicolumn{10}{|l|}{ Sayısı } \\
\hline \multicolumn{10}{|l|}{ Ağırlığı } \\
\hline \multicolumn{9}{|l|}{ A $\breve{g}_{1 r l} \breve{g}_{1}$} & \\
\hline \multicolumn{2}{|l|}{$\begin{array}{l}\text { Hektolitre } \\
\text { Ağırlığ }\end{array}$} & $-0.473^{* *}$ & -0.339 & $-0.477 * *$ & $-0.550 * *$ & -0.243 & 0.099 & & \\
\hline \multicolumn{10}{|l|}{ Verimi } \\
\hline Protein $\mathrm{O}$ & anı & -0.003 & 0.019 & -0.172 & $-0.488 * *$ & $-0.412^{* *}$ & 0.089 & 0.253 & 0.064 \\
\hline
\end{tabular}

\section{SONUÇ}

Günümüzde tek başına verimin yeterli olmadığı, yalnızca verim veya kalite özellikleri dikkate alınarak yapılacak çeşit seçimi yanıltıcı olup doğru çeşitlerin tercihini engelleyebileceği dikkate alınarak, kullanım amacına göre bazı kalite özellikleri ile birlikte verimin bir arada değerlendirilmesi gerekmektedir. Genel kanı olarak ıslah çalışmalarında verim artışının sağlanması yanında kalite özelliklerinde bir gerileme söz konusudur (Kahrıman ve Egesel, 2011). Bursa koşulları altında iki yıl süreyle yetiştirilen 9 tritikale çeşidinin verim kalite özelliklerinin belirlenmesinin amaçlandığı çalışmada, iki yıllık ortalama değerlere göre tane verimi yönünden Nörtingen, Karma-2000 ve Eronga çeşitlerinin yüksek verim verdiği belirlenmiştir. Kalite kriterleri bakımından çeşitler incelendiğinde, kalitenin belirlenmesinde kullanılan en kolay ve önemli özelliklerden birisi olarak kabul edilen hektolitre ağırlığı özelliği açısından Mikham2002 ve Alperbey çeşitlerinin en yüksek değerler aldığı gözlenmiştir. Tatlıcak-97 çeşidi ise diğer çeşitlere göre veriminin düşük olmasına rağmen en yüksek protein oranı değerlerini vermiş, Presto çeşidi ise bu çeşidi izlemiştir. Bu araştırma sonuçlarına göre verim ve kalite açısından yüksek değerler gözlenen çeşitlerin Bursa ekolojik koşullarında yetiştirilebileceği ve yürütülecek ıslah çalışmalarında daha verimli ve kaliteli çeşitleri geliştirmede ebeveyn olarak kullanılabileceği sonucuna varılmıştır.

\section{KAYNAKLAR}

Akgün I, Kaya M, Altındal D 2007. Isparta Ekolojik Koşullarında Bazı Tritikale Hat/Çeşitlerinin Verim ve Verim Unsurlarının Belirlenmesi. Akdeniz Üniv. Ziraat Fakültesi Dergisi, 20(2): 171-182.
Alp A 2009. Diyarbakır Kuru Koşullarında Bazı Tescilli Tritikale (XTriticosecale Wittmack) Çeşitlerinin Tarımsal Özelliklerinin Belirlenmesi. YYÜ Tar. Bil. Derg., 19(2): 61-70.

Anonim 2018. Bursa Bölgesi İklim Verileri. Bursa Meteroloji Bölge Müdürlüğü. Bursa. (Basılmamış veriler).

Atak M, Çiftçi CY 2006. Bazı Tritikale Çeşit ve Hatlarının Morfolojik Karakterizasyonu. AÜ Ziraat Fakültesi Tarım Bilimleri Dergisi, 12(1): 101-111.

Aydın N, Bayramoğlu HO, Özcan H 2007. Bazı Ekmeklik Buğday Genotiplerinin Verim Ve Başlıca Kalite Özelliklerinin Belirlenmesi. OMÜ. Zir. Fak. Dergisi, 22(2): 193- 201

Demir İ, Aydın N, Korkut KZ 1981. İleri Tritikale Hatlarının Bazı Agronomik Özellikleri Üzerine Araştırmalar. EÜ Ziraat Fakültesi Dergisi, 18: 227238.

Demirel K 2004. Kışlık Tritikale Genotiplerinde Agronomik Özelliklerdeki Genetik Davranışlar ve Sinıflar Arası Korelasyonlar. Eskişehir Osmangazi Üniversitesi. Fen Bilimleri Enstitüsü, Tarla Bitkileri Ana Bilim Dalı, Yüksek Lisans Tezi, $58 \mathrm{~s}$.

Deveciler H 2005. Uludağ Üniversitesi Tarımsal Uygulama ve Araştırma Merkezi Tarım Topraklarının Ağır Metal İçeriklerinin İncelenmesi. Bursa Uludağ Üniversitesi. Fen Bilimleri Enstitüsü, Toprak Ana Bilim Dalı, Yüksek Lisans Tezi, $33 \mathrm{~s}$.

Erekul O, Köhn W 2006. Effect of Weather and Soil Conditions on Yield Components and BreadMaking Quality of Winter Wheat (Triticum aestivum L.) and Winter Triticale (Triticosecale Wittm.) Varieties in North-east Germany. Journal of Agronomy and Crop Science 192: 452-464. 
Furan MA, Demir İ, Yüce S, Can Akçalı RR, Aykut F 2005. Ege Bölgesi Tritikale Çeşit Geliştirme Çalışmaları: Geliştirilen Ceşit Ve Hatların Verim ve Kalite Özellikleri Üzerinde Araştırmalar. Akdeniz Üniversitesi Ziraat Fakültesi Dergisi, 18(2): 251-256.

Genç İ, Yağbasanlar T, Ülger AC, Kırtok Y 1987. Çukurova Koşullarında Tritikalenin Verim ve Verim Öğeleri Üzerinde Bir Araştırma. Türkiye Tahıl Simpozyumu, 6-9 Ekim. s:103-114. Bursa

Geren H, Soya H, Ünsal R, Kavut YT, Sevim İ, Avcıoğlu R 2012. Menemen Koşullarında Yetiştirilen Bazı Tritikale Çeşitlerinin Tane Verimi ve Diğer Verim Özellikleri Üzerine Araştırmalar. EÜ Ziraat Fakültesi Dergisi 2: 195-200.

Gülmezoğlu N, Özer E, Taner S, Kınacı E 2007. Orta Anadolu Bölgesi Koşullarında Kışlık Tritikale Çeşitlerinin Tane Verimi ve Verim Öğelerinin Belirlenmesi. S.Ü. Ziraat Fakültesi Dergisi, 21(43): 53-60

Kahrıman F, Egesel C 2011. Farklı Ekmeklik Buğday Çeşitlerinin Agronomik ve Kalite Özellikleri Bakımından Değerlendirilmesi. Ordu Üniv. Bil. Tek. Derg., 1(1): 22-35.

Kaya A, Şanlı A 2009. Bazı Ekmeklik (Triticum aestivum L.) ve Makarnallk (Triticum durum L.) Buğday Çeşitlerinin Isparta Ekolojik Koşullarında Verim ve Bazı Verim Öğelerinin Belirlenmesi. Bitkisel Araştırma Dergisi, 2: 27-34

Kutlu I, Kınacı G 2011. Sulu ve Kuru Koşullara Uygun Tritikale Genotiplerinde Tarımsal Özelliklerin Belirlenmesi. Anadolu Üniversitesi Bilim ve Teknoloji Dergisi-C Yaşam Bilimleri ve Biyoteknoloji 1(1):71-82.

Kün E 1996. Tahıllar. A.Ü. Ziraat Fakültesi, Yayın No: 1451, Ankara, 431s.

Lermi AG ve Palta Ş 2018. Batı Karadeniz Ekolojisinde Farkl Tritikale (Xtriticosecale Wittmack) Çeşitlerinin Tohum Verimi Üzerine Araştırma. Bartın Orman Fakültesi Dergisi, 20 (2): 366-372.

Mut Z, Albayrak S, Töngel Ö 2006. Tritikale (Triticosecale Wittmack) Hatlarının Tane Verimi ve Bazı Özelliklerinin Belirlenmesi. AÜ Ziraat Fakültesi Tarım Bilimleri Dergisi, 12(1): 56-64.

Mut Z, Erbaş Köse ÖD 2018. Tritikale genotiplerinin tane verimi ve bazı kalite özellikleri. Anadolu
Tarım Bilimleri Dergisi, 33(1): 47.

Paksoy AH 2005. Kahramanmaraş koşullarında bazı tritikale çeşit ve hatlarının verim ve verim özelliklerinin belirlenmesi. Kahramanmaraş Sütçü İmam Üniversitesi, Fen Bilimleri Enstitüsü, Tarla Bitkileri Ana Bilim Dalı, Yüksek Lisans Tezi,44 s.

Polat KPÖ, Cifci EA, Yağdı K 2015. Ekmeklik Buğday (Triticum aestivum L.)'da Tane Verimi İle Bazı Verim Ögeleri Arasındaki İlişkilerin Saptanması. AÜ Ziraat Fakültesi Tarım Bilimleri Dergisi, 21: 355-362.

Tayyar Ş, Kahrıman F 2016. Biga Şartlarında Yetiştirilen Tritikale Genotiplerinin Verim ve Bazı Kalite Özelliklerinin Belirlenmesi. Adnan Menderes Üniversitesi Ziraat Fakültesi Dergisi, 13(2): 23-30.

Tohver M, Kann A, Taht R, Mihhalevski A, Hakman J 2005.Quality of Triticale Cultivars Suitable for Growing and Bread-Making in Northern Conditions. Food Chemistry,89: 125-132.

Tonk FA, İştipliler D, Tosun M. 2017. Bazı Ekmeklik Buğday (Triticum aestivum L.) Genotiplerinde Özellikler Arası İlişkiler ve Path Analizi. EÜ Ziraat Fak. Derg., 54 (1): 85-89.

Ülger AC, Yağbasanlar T, Genç İ 1989. Çukurova Koşularında Seçilen Yüksek Verimli Triticale Hatlarının Önemli Tarımsal Karakterleri Üzerinde Bir Araştırma. Doğa Türk Tarım ve Ormancılık Dergisi, 13(3): 1342-1362.

Ülker H 2017. Orta Anadolu Kurak Koşullarında Ekmeklik Buğday Çeşitlerinin Verim Ve Bazı Agronomik Özelliklerinde Genetik İlerlemenin Belirlenmesi. AEÜ. Fen Bilimleri Enstitüsü, Tarla Bitkileri Anabilim Dalı, Yüksek Lisans Tezi, $150 \mathrm{~s}$.

Ünver S 1999. Bazı Tritikale Hatlarında Verim ve Verim Öğelerinin İncelenmesi. Tarla Bitkileri Merkez Araştırma Enstitüsü Dergisi, 8(1-2): 82-92.

Yağbasanlar T 1987. Çukurova'nın Taban ve Kıraç Koşullarında Farklı Ekim Tarihlerinde Yetiştirilen Değişik kökenli Yedi Tritikale Çeşidinin Başlıca Tarımsal ve Kalite Özellikleri Üzerinde Araştırmalar. ÇÜ. Fen Bilimleri Enstitüsü, Tarla Bitkileri Ana Bilim Dalı, Doktora Tezi, $171 \mathrm{~s}$.

Yücel C, Baloch FS, Özkan H 2009. Genetic Analysis of Some Physical of Bread Wheat Grain (Triticum aestivum L.emThell).Turk. Agric. For., 33: 52-53. 